\title{
International labour market indicators : a proposal for development
}

Citation for published version (APA):

Teunis, U., \& de Grip, A. (1996). International labour market indicators : a proposal for development. Researchcentrum voor Onderwijs en Arbeidsmarkt, Faculteit der Economische Wetenschappen. ROA Reports No. 2E https://doi.org/10.26481/umarep.199602E

Document status and date:

Published: 01/01/1996

DOI:

10.26481/umarep.199602E

Document Version:

Publisher's PDF, also known as Version of record

\section{Please check the document version of this publication:}

- A submitted manuscript is the version of the article upon submission and before peer-review. There can be important differences between the submitted version and the official published version of record.

People interested in the research are advised to contact the author for the final version of the publication, or visit the DOI to the publisher's website.

- The final author version and the galley proof are versions of the publication after peer review.

- The final published version features the final layout of the paper including the volume, issue and page numbers.

Link to publication

\footnotetext{
General rights rights.

- You may freely distribute the URL identifying the publication in the public portal. please follow below link for the End User Agreement:

www.umlib.nl/taverne-license

Take down policy

If you believe that this document breaches copyright please contact us at:

repository@maastrichtuniversity.nl

providing details and we will investigate your claim.
}

Copyright and moral rights for the publications made accessible in the public portal are retained by the authors and/or other copyright owners and it is a condition of accessing publications that users recognise and abide by the legal requirements associated with these

- Users may download and print one copy of any publication from the public portal for the purpose of private study or research.

- You may not further distribute the material or use it for any profit-making activity or commercial gain

If the publication is distributed under the terms of Article $25 \mathrm{fa}$ of the Dutch Copyright Act, indicated by the "Taverne" license above, 


\section{International labour market indicators: a proposal for development}

ROA-R-1996/2E
$U$. Teunis
A. de Grip

Research Centre for Education and the Labour Market

Faculty of Economics and Business Administration

University of Limburg

Maastricht, March 1996 
CIP-GEGEVENS KONINKLIJKE BIBLIOTHEEK, DEN HAAG

Teunis, U.

International labour market indicators : a proposal for development / U. Teunis, A. de Grip. - Maastricht : Research Centre for Education and the Labour Market, Faculty of Economics and Business Administration, University of Limburg. ([Report] / Research Centre for Education and the Labour Market, ISSN 0922-8098; ROA-R-1996/2E)

Met lit. opg.

ISBN 90-5321-170-5

Trefw.: internationale arbeidsverdeling. 


\section{Contents}

Preface

1 Introduction 1

2 Theoretical considerations 5

2.1 Definition of indicators 5

$\begin{array}{ll}2.2 \text { Choice of indicators } & 6\end{array}$

2.3 Policy considerations: for whom, for what?

$\begin{array}{ll}2.4 \text { Scientific issues } & 10\end{array}$

$\begin{array}{ll}2.5 \text { Technical and practical issues } & 14\end{array}$

3 International key indicators: a proposal $\quad 17$

$\begin{array}{ll}3.1 \text { Guiding principles } & 17\end{array}$

3.2 A system of indicators: main structure 18

3.3 Definitions $\quad 20$

$\begin{array}{ll}3.4 \text { Elaboration of indicators } & 23\end{array}$

4 Availability of data 33

4.1 Types of datasources

4.2 Availability of data $\quad 35$

4.3 Analysis for four countries 36

5 Concluding remarks $\quad 47$

$\begin{array}{lr}\text { Literature } & 49\end{array}$ 


\section{Preface}

In 1994 the Dutch Ministry of Education, Culture and Science commissioned a research project for developing a proposal for a system of international labour market indicators with respect to the links between education and the labour market. Work on the project was done by U. Teunis and A. de Grip. J. Hoevenberg assisted in the datasearch activities. Valuable comments were given by $\mathrm{H}$. Heijke and F. Cörvers (ROA). P. van der Hallen and K. Timmerman (Higher Institute of Labour (HIVA), Belgium), Th. Jung-Hammon and M. Koller (Institute for Employment Research (IAB), Germany) and R. Wilson (Institute of Employment Research (IER), United Kingdom) assisted in our investigation on the availability of the required data in their respective countries. We highly appreciated their cooperation in the project. 



\section{Introduction}

Project goals

Solid information on the labour market and the match between education and the labour market is becoming more and more important. Investment in education is a main determinant of maintaining and increasing productivity and competitiveness, both on company and national level. Monitoring the effectiveness of these yields information for evaluation and policy on many institutional levels. In general, coordination of efforts on governmental, institutional and company level might be the main function of such monitoring.

For such monitoring, national information only is no longer sufficient. International comparison is an important tool in policy development at national level. Moreover, it contributes to policy and coordination on international level, especially between the Member-States of the European Union. From another point of view, all kinds of institutions are in growing demand of international information on the labour market and the links between education and the labour market. These institutions each play a particular role in the internationalization of labour markets within a 'Europe without frontiers', be it in the real of study- and career guidance, recruitment of personnel, validation of certificates, advisory services, educational planning etc.

Of these two types of international information sketched above, i.e. international comparison and internationally oriented information relevant for institutions in the fields of labour market and education, the former has been paid most attention. Most impressive here is the OECD project on international indicators on education INES (OECD, 1994). Within this project, development of a set of indicators on links between education and the labour market is still in development (Jos, 1995).

For the latter type of use, the comparative nature of the indicators is not the most relevant aspect. Moreover, comparative information tends to be rather abstract and aggregated. More specific information is often needed for institutions with specific functions within the prementioned fields.

In view of this situation, the (Dutch) Ministry of Education, Culture and Science commissioned a research project for developing a proposal for a system of international labour market indicators focusing on this latter type of use. The Ministry actively furthers internationalization of education, especially in the fields of vocational, professional and higher education, and also as a contribution to the integration of the labour markets on european scale. 
This task was given to the Research Centre for Education and the Labour Market (ROA), which had previously developed an indicator system on a national scale with goals and functions comparable to those now intended on an international scale. This information system has been developed and managed by ROA since 1986. It presents extensive information on the labour market and the links between education and labour in the Netherlands, serving several functions especially in the realm of advice on study- and career choice, the public employment service and policy concerning labour market and education.

Several initiatives at the level of the European Union also gave rise to steps towards the development of an international system. These initiatives are connected with the ongoing integration of the economies within the European Union, the principle of free mobility of labour within the $\mathrm{EU}$ and the mutual openness of the labour markets, the goal of internationalization of (vocational) education oriented to the European labour market and the need for information for monitoring, evaluation and policy connected with these developments (Europese Commissie, 1994; CEDEFOP, 1995).

In short, then, the goal of the International Labour Market Indicators project is to develop a proposal for a comprehensive system of indicators on the labour market and the matches between labour market and education. This development should be done firstly, to support the activities of any institutions with functions in the internationalization of economies and education; secondly, to present information for evaluation and policy. Also the possibilities for actually developing the system and for an institutional structure for developing and maintaining it are part of the project.

\section{Project conditions}

The International Labour Market Indicators are designed to have comparable functions to the Dutch national system but on an international level. This means they will serve a heterogeneous and partly unknown group of institutions and persons. This poses special conditions on the type of indicators, the data comprised, the method of presentation and publication and the organization of the project. These conditions were formulated in an early stage of the project, and served as principles in the exploitation of the theoretical framework and the design of potential indicators.

1. The system is designed primarily for serving and supporting agencies with an active role in the fields of study- and career guidance, public employment services and education, though not excluding other functions, especially policy oriented information provision and evaluation.

2. To serve these functions, the data in the indicators must be at a rather low 
level of aggregation. Finding the optimal point between, on the one hand, an integrative, compact and convenient arrangement of information, and on the other hand enough detail for the various user groups will be a main point of attention in developing the system.

3. Completeness on each participating country is more important than complete comparability. Therefore, the indicators should be filled with the best fitting data available in each participating country: comparable where possible, not directly comparable if these are the best available data.

4. Costs for running and using the system must be limited, lest the use will be out of reach for the target institutions. This will be strived for primarily by using data available in the participating countries (labour force surveys, population censuses, administrative data, statistics on education etc.) and available research, esp. surveys on school leavers. Conversion of data for the sake of comparability is only done if cost efficient. Datasets on EUlevel, esp. from EUROSTAT, may have additional functions.

5. Limitation of costs is also strived for by the proposed organizational structure for developing and running the system. Key to this structure is the cooperation of institutions with comparable tasks to ROA in each of the participating countries.

6. The system to be developed leaves open options on the method of publication in relation to specific target institutions. Therefore, a wide range of possible indicators and their information base will be explored. A modular way of building up the indicator system and presenting the outcomes must be explored.

Project activities

This first exploration into the possibilities of developing a system of international labour market indicators was done mainly in three ways.

Firstly, a literature study was done on the functions, development and maintenance of indicator systems. This study was done in order to further refine the preset conditions and to underpin choices on types of functionalities to be strived for, the target institutions, indicators to be developed and types of data to be used.

Secondly, a gross inventory of the availability of datasets and research outcomes was done. This gross inventory was limited to four countries (Belgium, Germany, Great Britain and The Netherlands) and the available EUROSTAT data. The results are presented here as an example of the type of data analysis to be carried out eventually for all countries participating in the actual development of the system.

Thirdly, a set of potential indicators was developed, reflecting both theoretical 
considerations and the potential availability of data and research. The Dutch information system on education and the labour market served as a model in this stage. The developed indicators are, at this stage of the project, seen first of all as illustrative, leaving open further development in cooperation with partners in the actual development and maintenance of the system.

The inventory of available data and research was done by analysing publications and by acquiring information from national institutions within the three countries prementioned (ROA serving itself for The Netherlands). Also comments and information were given by letter and telephone. With these institutions the possibilities for cooperation in developing and running the system were discussed in an open and orienting way. The institutions are:

1. For Belgium: HIVA (Higher Institute of Labour), a research institute connected to the University of Leuven (Louvain).

2. For the federal republic of Germany: IAB (Institute for Employment Research), the research institute of the Federal Bureau of Labour.

3. For the United Kingdom: IER (Institute for Employment Research), a research institute connected to the University of Warwick.

Structure of this report

In chapter 2, the results of the literature study are presented. Conclusions pertinent to the indicator system to be developed are highlighted. In chapter 3 , the provisional system of indicators is presented, with some explanations on single indicators. The main underpinning of the proposed system though is to be found in chapter 2 . Chapter 4 presents the main results of the inventory on the availability of the required data. In chapter 5 some concluding remarks are made, in particular with respect to some alternative strategies to develop a European wide system of international labour market indicators. 


\section{Theoretical considerations}

\subsection{Definition of indicators}

Several definitions of the concept 'indicator' have been proposed. Some of these definitions focus on characteristics of the figures and texts named 'indicators': quantitative or qualitative indicators, composite figures as opposed to simple 'statistics' etc.. This type of definition is probably not very fruitful in this context. Other definitions are based upon the type of use to be made of the indicators. This is the type of definition given by Jaeger (1978, op. cit. in Nuttall 1994):

"... all variables that a) represent the aggregate status or change in status of any group of persons, objects, institutions, or elements under study, and that b) are essential to a report of status or change of status of the entities under study, should be termed indicators.... I would not require that reports of status or change in status be in quantitative form, for narrative is often a better aid to comprehension and understanding of phenomena than is a numeric report."

In this report also a 'functional' definition of indicators is followed. That means that in selecting and describing the indicators in the proposed system the functionality for a group of specific institutions, i.e. the potential use to be made of the indicators, has been the leading consideration. The theoretical considerations concerning the construction of the indicator system and of the single indicators concentrate upon the optimalization of this functionality.

In most definitions found in literature, analysis and discussion are no part of the indicators as such. The indicators can be the reason for and an input to analysis and discussion by or in order of those using them, but they should be presented without comment to avoid the value judgements of the provider(s) of the indicators interfering with the information in the indicators. Of course, values and value based choices are inevitable in constructing and selecting indicators and the datasources to feed them. These values and choices should be made explicit wherever they are non-trivial. However, having been constructed and selected, the indicators should be run as 'objectively' as possible, leaving all freedom of use and interpretation to those for whom they are meant. This holds especially in the case of the International Labour Market Indicators, which are meant to serve the interests of a rather heterogeneous group of institutions and persons within the institutional context of several countries.

Other elements of definitions found in literature that are relevant here are:

* Longitudinality: the indicators should be used over a longer period, as the 
differences between yearly figures ("change in status") and the trend over some years as such convey a considerable part of the potential information value of the indicators.

* Continuity: to do their job the indicators should be stable over a long period, both in terms of definitions and ways of constructing them (templates) and in terms of the statistics and research used as input. This is an important condition for the potential providers and financers of the indicator system.

\subsection{Choice of indicators}

As Nuttall (1994) points out, the process of developing, selecting and implementing indicators is steered by often conflicting considerations within rather different realms: policy considerations, scientific and technical issues, practical considerations and, in the end, elements of power (who chooses ?). Nuttall sees the functionality of indicators mainly in relation to policy processes within specific organizations at a specific level. That means that the goals and values of the target organizations form the dominant considerations in developing and selecting indicators. Nevertheless the conflict with other types of considerations may be a realistic one.

Policy considerations tend to stress simple indicators, deriving from available (statistical) information and relating directly to current policy themes. If policy considerations are not counterweighed by other interests, the indicator system is in danger of being too much determined by the 'political agenda' (and so dismissed when the tide turns) and of an irresponsible reduction of the information base. Another danger of too simple indicators is influence on the behaviour of the monitored system, which tries to 'live up to' the norms embodied in the indicators. A third danger is interpretation of the indicators as causal relations directly underpinning conclusions on policy. Nuttall therefore advises the development of indicator systems to be interpreted as a whole. In such systems the single indicators cannot be interpreted apart without loss of information.

Scientific and technical issues refer to the problems of bridging the gap between a global model of indicators in concepts relevant to policy on the one hand, and the operationalization of indicators in concepts precisely enough to calculate them on the other. Often more than one operationalization is possible. Choices are not value-free and tied to the scientific tradition within which they are made (economic versus sociological etc.). Questions of validity and reliability should be posed here. Scientific norms may also conflict with policy decisions on the point of the costs of the system. An indicator system designed too much from a scientific interest or from a specific disciplinary tradition, or a system maintained by a scientific institution, runs the risk of alienation from the policy interests which it was supposed to serve 
originally.

Practical considerations refer to important conditions for being relevant to the target group: indicators should be timely, comprehensible and few in number. Being up to date may pose practical and costs problems. Comprehensibility and low number may conflict with scientific interests. Another problem here may be the dependency on data providers and the cost limits. Choices are necessary regarding presentation with or without interpretation and comment. Comment may further comprehension but may conflict with policy goals ('unwanted conclusions'). As stated before, it is difficult to give valuefree comment not interfering with the information in the indicators. In addition to the cost limits to developing and maintaining the system, also the 'costs of access' in terms of time involved in deriving, interpreting and using the indicators should be considered.

However, choices are necessary, so power is a factor. In Nuttall's view, the important questions here are: for whom is the indicator system meant, and who pays? As policy agencies are often both the target group and the provider of money, their considerations are often dominant. For more or less rational decisions an analysis of the structure of interests of all parties involved in developing and maintaining an indicator system may be helpful.

Analysing these interests and considerations should lead to criteria for choosing, developing and evaluating indicators. Nuttall (in advising upon the OECD-project on International Education Indicators) proposed six principles:

"* Indicators are diagnostic and suggestive of alternative actions, rather than judgemental.

* The implicit model underlying a set of indicators must be made explicit and acknowledged.

* The criteria for the selection of indicators must be made clear and related to the underlying model.

* Individual indicators should be valid, reliable and useful.

* Comparisons must be done fairly and in a variety of different ways.

* The various consumers of information must be educated about its use."

Applying the four groups of considerations to choices to be made in selecting and developing the proposed system of International Labour Market Indicators yields some conclusions on choices to be made in the case of this specific project.

\subsection{Policy considerations: for whom, for what?}

In the first place, the initiative for developing a system of International Labour Market Indicators comes from the scientific world. The idea and initiative come from 
ROA. The proposed system elaborates upon the existing national information system, which has a clear relationship with a number of Dutch institutions in the fields of vocational and educational guidance, public employment services and educational policy, and a clear meaning for specific policy- and workprocesses of these institutions. The international system does not (yet) have these relationship and meaning. One of the goals of the development phase of the system thus will have to be to build these up, lest the system will be merely of scientific interest, not gaining general support and so shortly lived.

In the second place, the international character of the proposed system poses a critical condition. It will mean acquiring the commitment of institutions with comparable tasks, but often organised in different ways within different countries. Partly, the system will be run for anonymous 'types of institutions', for whom the indicators will be an item on offer on the 'market of information' with which they do not build up a specific commitment. This has two consequences for the proposed system. The indicators must on the one hand be general enough to serve diverse needs and ways of use (instead of being developed for a specific institution that pays and uses). On the other hand they must be specific and informative enough to acquire their place on the 'market'. This means a heavy claim on the quality and presentation of the system.

The third point also concerns the international character of the proposed system. What is the function, the 'added value', of building an international system, compared to national systems in each of the participating countries ? Two things come up: comparison and use of international data for specific work processes. Comparison is the main goal of the OECD-project International Indicators of Educational Systems (INES). Comparison between the inputs, processes and outcomes of national educational systems can be very important for evaluation and policy preparation both on international and national level. In particular differences of outcomes between countries in comparable developmental stages might point to important factors in producing these outcomes, though conclusions can only be drawn from further investigation into causal relationships (Bottani \& Tuijnman, 1994). If comparison is the main goal, integrating classifications, building up comparable datasources and integrating theoretical models would become main points of interest.

Practical use of international data happens for example if labour market institutions gain information on the situation in neighbouring countries to anticipate and guide future migration streams, if a company explores the possibilities of recruitment of specific skilled workers in a neighbouring country etc. Especially within the northwestern European countries, currently rapidly integrating their economies, numerous foreseen and unforeseen questions might be posed to an international 
dataset. For this goal, complete comparability of classifications, datasources and methods is not the main condition; completeness and a relatively low level of aggregation of data are more important.

As is the case for the Dutch national system, which served as a model in exploring possibilities for the International Labour Market Indicators, the second orientation is dominant, though the first (evaluation and policy oriented comparison) is not excluded. As will be seen this has several consequences for the indicators to be proposed.

Last but not least, choices have to be made as to kind of institutions and persons that might be served by the proposed system. Partly this will be the outcome of the development process, as the system will be offered on an open 'market' of information products. Yet the present functionality of the POA-system and the exploration in another context (Teunis 1995) gives the impression that the following types of institutions and persons in particular, might be served in the following ways:

a. The employment services: are interested in information that supports their functioning. This is both strategic information on labour market developments and prospects on the labour market, quantitatively (demand - supply) and qualitatively (development of qualification requirements etc.) as well as specific information for guiding transnational migrants, transborder placements etc.

b. Guidance in educational and jobcareer choices: information needed for adequately informing people and guiding them to international careers; insight into possibilities to find a job over the border holding specific qualifications now and in the future; insight into chances of success etc. This function is for example suggested by the -former- EU PETRA-project (PETRA National Centre, 1994).

c. Policy of educational authorities: generally information needed for an international perspective in the organization and content of education. Also information for planning courses on possible demand from over the border, planning specialist courses in cooperation with other schools on an international, esp. euregional, level etc.

d. Policy of private and public employers: information on labour market developments and future bottlenecks for recruitment, esp. the possibility of recruiting scarce qualifications over the borders.

e. Public policy agencies at national and community level: being used as input to policy preparation and evaluation, the system might serve several functions, for example:

- The system indicates possibly problematic situations in the transition from school to work, both quantitatively (e.g. employment) and qualitatively (e.g. over- and undereducation at the job). The system then serves the function of monitoring the transition (esp. if published periodically). The comparative nature 
of the indicators can point to possible causes and clues for further investigation.

- The system might serve as a means for evaluating parts or aspects of the educational system, the labour market and the transitions between them, by monitoring the functioning of the systems in several countries.

- The system might indicate comparative advantages in the international competitive position due to skill potentials of the labour force.

- The system might point at differences between countries possibly impeding the development of a common market, giving rise to policy on euregional, intergovernmental or community - level.

f. General public: issues on the relationship between education and labour, and differences between countries on that point, are often 'hot issues' in the public debate. The system can provide actual data for this debate, for example to the public media.

g. Scientific users: the system might suggest possibly interesting points for further scientific analysis; it can put data at the disposition of political and scientific annalists.

\subsection{Scientific issues}

As to the second group of considerations proposed by Nutall, two themes are considered here: the theoretical backgrounds from which the system of indicators will be developed and some more technical issues on selecting the indicators and the underlying datasources.

\section{Theoretical backgrounds}

Theoretically the proposed system derives from the tradition of the economics discipline in describing the functioning of the labour market in terms of the structure of labour demand and supply and the resulting labour market (im)balances. The indicators have a special focus on relationships between educational outcomes and labour market structures and developments: both in structural and the dynamic 'mismatch' indicators, the educational background of the participants on the labour market and their occupational and sectoral position are related in various ways. This is done in consideration of both theoretical grounds and the intended ways of use of the labour market indicators (see the foregoing).

As to the theoretical grounds, Heijke (1993) and Rumberger (1994) describe three current theoretical frameworks for describing and explaining the role of education in the labour market and the development of the economy: the 'human capital theory', the 'screening theory' and the 'job competition model'. In addition to these three theoretical positions the 'job matching theory' should be mentioned (see also Van 
Eijs and Heijke, 1996).

The 'human capital theory' sketches education as an investment in human productivity. A direct relationship is supposed between education (described as number of years of education completed) and productivity and between productivity and wage levels. This means that the returns or 'profits' from individual choices on educational career can be calculated in terms of higher income. However, this return has to be balanced against costs (costs of study and the 'opportunity costs' with respect to the income foregone during study).

The 'screening theory' assumes that on the labour market the attained education is not primarily seen as an investment in productivity but as an indication of the relative intelligence and capability. Certificates are therefore used as a means of selection. The individual investment in education does not lead to higher productivity but makes the certificate-holder visible for selecting employers.

The 'job competition model' also does not view education as an investment in productivity. The assumption here is that the actual qualification for a specific function is acquired in the profession, by ways of experience on the job and continuing training. Initial education though does reduce the costs of this training. Education, and esp. the level of education completed, is thus seen as an indication of the 'trainability' of workers. Implication is that employers always will try to select the workers with the highest skill levels available, thus reducing their training costs, which will lead to crowding out processes and overeducation under conditions of oversupply of labour.

The theory of job matching partly obviates the drawbacks of the prementioned theoretical frameworks (Arents, Heijke and Koeslag, 1996). In this theory, interactions between personal abilities and job characteristics mainly determine an individual's productivity in a job. On the one hand, the demand side of the labour market is assumed to consist of jobs with different qualification requirements. On the other hand, the supply side consists of individuals who have acquired qualifications by means of education and training. Individual abilities make people more or less suited for specific jobs, with consequences for their opportunities to get those jobs. Those abilities are interpreted in terms of comparative advantages for a specific job. This theory has two important implications. Primarily, not only the quantity, i.e. the level of education makes a difference (as in human capital theory) but also its nature: particular qualifications offer comparative advantages. Secondly, selecting the 'highest available' does not yield profit for the employer without limitations (as in the job competion model): as the gap between the level of the job and of the qualification grows to wide, the comparative advantages of being overqualificated disappair. This limits the imbalancing effects of overeducation. 
Implication of this theory for the indicator system is that information on the educational background must cover both the levels of education and the subjects of study.

These four theoretical frameworks suggest requirements for different types of information about the labour market (Cf. Heijke 1993). These differences might lead to (partly) different sets of indicators. In this study the position taken is to combine the various insights and to develop a system of indicators that might be interpreted from different theoretical viewpoints. The indicators highlight the relationship between the position reached in education and the position on the labour market in several ways. These relationships might be interpreted both from a 'human capital'and from a 'screening' - viewpoint. The 'job competition model' predicts some particular effects of labour market imbalances, esp. crowding out and overeducation, which are described in part of the indicators.

However, also some limitations of and critique on the current theoretical frameworks are taken into consideration. In the light of the critique on esp. the human capital theory mentioned by Rumberger, it is important that the indicators not only relate the quantity of education consumed (number of years of education) to economic outcomes but also the quality or type of education. This allows for far more refined analyses, as the outcomes of education might differ between the various types of education, between economic sectors and between occupational groups.

\section{Collective outcomes}

A second point refers to the focus of the theoretical frameworks upon the individual profits and costs of education. Heijke and De Grip (1995) also focus on the macroeconomic outcomes of an effective link between education and labour market and so on macroeconomic costs of labour market imbalances. In this view, investment in education is investment in 'human capital', which yields individual profits, but also important collective profits: boosting economic growth and lowering the degree of joblessness. Labour market imbalances on the other hand lead to collective costs in terms of higher degree of joblessness and the social costs of this, a suboptimal level of productivity and company costs of open vacancies. The function of the information system is to further the collective profits and prevent costs, especially by way of furthering the transparency of the labour market in order to prevent imbalances.

Another collective outcome is the position in the international competition of economies and the role of education in the competitiveness of national economies. As Rumberger (1994) states, questions on the competitiveness of the American, and more generally the western, economies towards the newly industrializing 
countries have induced a renewed interest in indicators on the relations between education and economy, after having been dismissed for a long period.

Cörvers et al. (1995) analyse the role of human capital in the international competitiveness of economies within two alternative theoretical frameworks: that of the comparative advantages of national economies (relative wage level and relative labour productivity) and that of human capital furthering national productivity (knowledge as production factor and as factor in the production and diffusion of new technologies). The assumption here is that the effect differs per economic sector, being higher in sectors depending more on complex and knowledge-intensive production processes. In comparing the labour productivity and the endowments of intermediate and highly skilled workers of sectors in Germany and The Netherlands, this assumption was partly corroborated.

In the light of the focus on international competitiveness, the international indicators might be important as a means for international comparison (some limitations on this point have been mentioned in the foregoing). In line with the assumptions of Cörvers et. al. (1995), some macroeconomic indicators are added in order to relate comparative advantages of the national economies to the indicators on the labour markets: relative wage level and labour productivity per sector, an indicator of 'human capital investment' per sector.

\section{Static or dynamic ?}

This point concerns the static or dynamic nature of the indicators. The indicator system proposed by Rumberger $(1994)^{1}$ is more or less static (describing the actual situation), whereas the model proposed here is partly dynamic (describing current and future developments), containing forecasts and 'risk indicators'. A dynamic model was developed within the Dutch national project, partly based upon earlier examples, o.a. the IAB dispersion coefficients (see e.g. Sheldon, 1985 and Warnken, 1986). After all, the main goal of this model is not description but influence, providing tools for advising individuals on job- and career choices, for policy development etc. (De Grip \& Heijke, 1995). The combination of forecasts and 'risk

1. Rumberger proposes seven "economic indicators of education systems":

"1. educational qualifications of the population;

2. employment status of the population;

3. characteristics of firms and jobs in the economy;

4. extent of 'mismatch' between the qualifications of the population (No. 1) and the characteristics of firms and jobs (No. 3);

5. formal and informal training opportunities of workers;

6 . workplace attitudes and behaviours;

7. earnings." 
indicators' allowed for such practical use without running the risks of the naive use of indicators on the current labour market situation or the use of unconditioned manpower requirement forecasts due to cobweb processes (Borghans, 1993). Also the proposed qualitative indicators on trends in technology, economic structure and company organization partly serve as an 'early warning device', indicating that trends might bend in the near future.

Other differences between both proposals are of a more practical nature. The indicator system proposed here is designed to be primarily based on existing statistics and research, which do not allow for the indicators on 'formal and informal training opportunities for workers' and 'workplace attitudes and behaviours'. This does not mean that these indicators do not fit into the choosen model; maybe additional datasets might facilitate partially incorporating into the system proposed here.

\subsection{Technical and practical issues}

On a more technical level, two points have to be mentioned. Firstly, in view of the intended functions of the system, completeness is of higher priority than full comparability. That means that where possible comparable figures on the participating countries will be used, but where this is not possible (in terms of classifications used and/or available aggregation level) best fitting figures will be used. If a certain figure is lacking in one of the countries it will nevertheless be used for the other.

Secondly, compared with other proposed systems of international economic indicators, as for example the 'network B-indicators' in INES (Jos, 1995), the indicators proposed here will be presented at a low level of aggregation. This too is done in view of the intended practical functions, which need more details than international evaluative comparison only. Of course, practical considerations (money, manageability, availability of data) put limits to the level of detail, as do empirical indications on the compartments of the labour market to be discriminated, still yielding reliable and valid information.

\section{Practical considerations}

The practical conditions mentioned by Nuttall (1994), timeliness, comprehensibility and parsimony in number, are all relevant here. Being up to date will be a problem for an indicator system to be filled by cooperating institutes in different countries, deriving data from a number of different sources in those countries. Yet, being in time will be essential for the institutions that will commit themselves to buying and using the indicators, given that a practical and policy-oriented use is intended. Strict 
arrangements will have to be made on both frequency and scheduling of updates.

Comprehensibility and parsimony may conflict with the validity of the indicator system and with the conditions for the intended ways of use. Comprehensibility will be furthered by a clear way of presenting, ordering and naming the indicators, so that they 'speak for themselves' as much as possible. Yet the international character and the desired level of aggregation will result in a large number of indicators. In course of actually developing the system solutions will have to be found. A possibility is a modular system, which would mean developing the indicator system not as a single publication but as an 'information system' that can yield tailormade output.

Nuttall (1994) pleads for presenting the indicators without further comment, as the "comment almost inevitably reflects the values of the commentator and thus can lead to political difficulties". This choice is not made here, as interpretation may be wanted by the institutions using the system, especially if this comment is relevant to their specific use, Moreover, technical 'warnings' on coverage, meaning of terms etcetera should be given, especially in an international context. The Dutch national information system is interpreted especially in view of use in study- and career guidance. In the most recent report (ROA, 1995) the labour market mismatches forecast are also interpreted from the viewpoint of the future recruitment problems that employers in the various economic sectors will probably face. Interpretations are essential to the intended way of use. In the case of the international indicators, with several more or less heterogeneous groups of potential users (see foregoing), it will be of great importance to produce tailor-made interpretations of the values of the various labour market information for all relevant user groups. Possibilities, to be explored later, are to separate figures and interpretation and to develop several interpretive documents for specific user groups (for example on labour market policy, on study- and careerguidance, on national policies etcetera). Then it is essential that the interpretation of the information is the scientific responsibility of the commentator, using the indicators as inputs to his/her comments, and that the eventual policy interpretation is the responsibility of the labour market actors themselves. 



\section{International key indicators: a proposal}

\subsection{Guiding principles}

The theoretical foundations underpinning the proposal for a system of International Labour Market Indicators have been sketched in the preceding chapter. In chapter 1 , also some conclusions were drawn on the project conditions. The foundations and conditions are recapitulated into some principles to guide the selection and structuring of the proposal.

Furthering transparency: a main function of the indicator system is to further transparency of the labour market in order to reduce the collective and private costs of imbalances. In order to do so, the main structure of the system is based on an economic model comprising the structure of employment (II in the main structure; see section 3.2) and (im)balances on the labour market (III). In general the indicators refer to the three dimensions that are crucial for the structure of labour demand and/or supply and the resulting allocation process on the labour market: economic sector, occupational group and type of education, respectively. However current imbalances are not sufficiently indicated by unemployment and vacancy rates. Also indexes on over- and under education (III) indicate imbalances.

Monitoring of human capital: another main function of the proposed system is monitoring of the development of human capital, both qualitatively and quantitatively. As the 'production' of human capital takes place for a part in initial education, the transition from education to work is paid special attention; a special set of indicators $(V)$ is devoted to this. Some of the entities and attributes in the indicators have special meaning at this point. 'Type of education' is important as it indicates the nature of the human capital built up in the working population. 'Gender' also refers to possible differences in profit of investment in human capital between men and women, due to discrimination, lower labour participation of women etc. 'Nationality' also has this meaning within the system.

Static and dynamic: besides static indicators, depicting the actual structure and the (im)balances, dynamic indicators are also presented, giving insight into trends and prospects. The indicators on the future labour market (VII) are of crucial importance for study- and career choice and for policy choices in all kind of institutions. The risk indicators (IV) are needed to make a sound use both of the indexes on actual imbalances and prospects. The qualitative indicators (VI) have two functions in this respect: they serve as 'early warning system', drawing attention to possible future trends, and they offer some interpretive framework for interpreting the trends in the prospects. 
Macro-economic framework: some general macro-economic indexes are added (I). These partly serve as background for interpreting labour market developments. Also, these might be interpreted in the light of national competiveness.

Clear structure, completeness: the structure of the indicator system and the title of the single indicators are chosen for transparency; as far as possible the indicators should 'speak for themselves'. The indicators as such are made as comprehensive as possible, often combining several dimensions and attributes to a single index. The high level of detail wanted for the intended use refers to the data, not to the structure of the indicators. A low level of aggregation is especially strived at for the data on the three crucial dimensions in the system: economic sector, occupation and type of education.

Comparability: the indicators should be defined and derived in the same way accross all segments of the labour market in a particular country. Of course, this also holds for international comparisons. However, as stated in chapter 1, completeness is more important than complete comparability.

Where relevant, specific considerations on form and content will be given with the single indicators in section 3.4 .

\subsection{A system of indicators: main structure}

The main structure of the indicators system proposed is:

\section{Comparative position of national economies}

I.1 relative wage level

I.2 relative labour productivity

I.3 endowments of intermediate and highly skilled workers

\section{Structure of employment \& recent trends}

II.1 structure of employment

II.2 participation indexes (employed, unemployed, inactive)

II.3 gender structure of employment

II.4 age structure of employment

II.5 type of employment (paid employment, self employed, other employment)

II.6 atypical employment:

II.6.1 part-time work

II.6.2 temporary jobs 
II.7 nationality

\section{Current labour market balances}

III.1 open discrepancies:

III.1.1 vacancy rate

III.1.2 unemployment rate

III.2 hidden dicrepancies:

III.2.1 rate of overeducation

III.2.2 rate of undereducation

III.3 typology of relation between open and hidden discrepancies

III.4 wages

\section{Risk indicators}

IV.1 flexibility of workers:

IV.1.1 sectoral flexibility (by occupational group)

IV.1.2 occupational flexibility

IV.1.3 sectoral flexibility (by type of education)

IV.2 skill flexibility of recruitment

IV.3 cyclical sensitivity of employment

V. Transition from school to work (school leavers information)

V.1 structure of employment

V.2 unemployment rate

V.3 hidden discrepancies:

V.3.1 rate of overeducation

V.3.2 rate of undereducation

V.4 type of employment (paid employment, self employed, other employment)

V.5 atypical work:

V.5.1 part-time work

V.5.2 temporary jobs

V.6 wages

V.7 participation in training

VI. Qualitative developments

VI.1 technological and structural trends

VI.2 degree of job content change 


\title{
VII. Future labour market: short and medium term forecasts
}

\author{
VII.1 inflow of school leavers on the labour market (2 - 5 years forecasts) \\ VII.2 $2-5$ years forecasts of demand: \\ a - c expansion demand \\ d - $f \quad$ replacement demand \\ g- $\mathrm{i} \quad$ job openings \\ VII.3 interpretations: \\ VII.3.1 labour market perspectives \\ VII.3.2 recruitment perspectives
}

\subsection{Definitions}

The definitions bear upon the entities on which the indicators present data and the attributes of these entities, discriminated into labour market dimensions and status attributes.

Wherever possible, definitions are derived from EUROSTAT's Labour Force Survey (1992). This holds for 'population', 'labour force', 'employment', 'types of employment', 'atypical employment', 'unemployment', 'inactive persons' and 'nationality'. However, the definitions are adapted for the use outside of the context of a labour force survey. In particular, the element of reference periods is left aside; in other datasources (statistics, registrations of unemployed etc.) normally other reference periods are used. Most definitions are also globalised to allow for adaptations to national statistics and surveys in the participating countries. The 'types of employment' and 'atypical employment' refer to subcategories within EUROSTAT's 'employment'.

Of the attributes, the definitions of 'sector' and 'occupational group' are derived from those in the NACE rev.1 and ISCO-88, also used by EUROSTAT. For 'type of education' a more elaborated definition is proposed (op. cit.). Not defined within the Labour Force Survey are 'school leavers', 'vacancies' and 'outflow from initial education'.

The precise definition and the classifications and levels of aggregation to be used will be elaborated in the actual development of the indicators. This policy is chosen as the availability of data and the classifications and levels of aggregation used may vary between the participating countries. After all, as motivated in section 2.2.1, completeness and a rather low level of aggregation of data are, for the proposed use of the system, of more importance than complete comparability. Generally the policy will be:

- An international classification (such as ISCED, NACE, ISCO) will be used where 
possible. However, if an essential piece of information is only available in a national classification (and/or only nationally available on the required level of aggregation, and/or more reliably etc.), this classification is used in a way best fitting the international classification.

- The level of aggregation will be choosen per indicator and per country on grounds of availability of data, practicality and relevance for practical and policy goals.

Entities

All indicators refer to one of the following entities:

- Population 15 - 65 years: the population of working age, i.e. the potentially employed part of the total population;

- School leavers: persons who left a type of initial education without continuing in another type of education, position about one year after school leaving (employed, unemployed, inactive, combining employment and training, combining unemployment and training);

- Unemployed persons: persons in unemployment (see at 'status attributes');

- Vacancies: officially registered vacancies and/or vacancy - data in surveys;

- Outflow from initial education: all persons leaving a type of initial education (definition: see below), with or without a diploma or certificate.

Used as parameters, but not as such shown in indicators, are two other entities: forecasts of employment and forecasts of age structure.

Attributes

For these entities a number of attributes are used, roughly to be discriminated as 'labour market dimensions' and 'status attributes'.

\section{Labour market dimensions}

Main dimensions are 'sector', 'occupational group' and 'type of education'. Generally these are defined here as:

- Sector: the type of economic activities, described on the level of aggregation used and within the classification used.

- Occupational group: the type of occupation or profession, described on the level of aggregation used and within the classification used.

- Types of education: combinations of levels and specific contents within the national structure of education, normally leading to a first entrance to the labour market (i.e. initial education). 
The definition of 'types of education' is more elaborated than in the Labour Force Survey (EUROSTAT 1992), which is based upon the 'levels' of general and vocational education only. As is shown in the ROA information system on education and the labour market, the specific types of (esp. vocational) education, such as technical -, administrative -, health care - etc., may have quite different relations with sectors and occupational groups. Therefore, 'levels' have to be combined with 'contents' into 'types'. This typology will be worked out later, for reasons prementioned.

'Initial' discriminates education from 'training', normally combined with work or joblessness. As the types of initial education are referred to with several terms in the countries concerned ('education' and 'training' in the UK, 'Bildung' and 'Ausbildung' in the BRD, etc.), here 'education' is choosen as the umbrella term. Apprentice training that is still considered as initial (German 'duale System', Dutch 'leerlingwezen') is also comprised in education.

\section{Status attributes}

- Training: training after initial education, normally combined with work or unemploment: specific function-oriented courses, on-the-job training, courses of manpower agencies etc.

- Labour force: all persons of 15 - 65 years in employment and all unemployed persons.

- Employment: all persons of 15 - 65 years working.

- Types of employment: employment is broken down into

. paid employment, i.e. continuously receiving wage or salary (including periods of absence with ongoing payment and/or prospect of return;

self employed people;

people doing other forms of work for wage, profit or family gain, in cash or in kind (working in home, on family farms etc.).

- Atypical employment: part time jobs, temporary jobs (contracts of limited duration).

- Unemployment: all persons of 15 - 65 years without work, currently available for work and seeking work ${ }^{2}$.

- Inactive persons: persons of 15 - 65 years not in employment and not in unemployment (among others full time pupils and students, early retired etc.).

- Gender: man - woman

- Nationality: citizens and people of other nationalities, if possible broken down to

2. For use of national statistics on unemployment, modifications of this definition might be necessary. 
citizens of other EU-countries and non-EU foreigners.

\subsection{Elaboration of indicators}

\section{Comparative position of national economies}

These indicators may be interpreted as gross macroeconomic background indicators, giving an impression of the relative position of the national economies of which the status and dynamics of the labour market is described (in absolute terms) in all other indicators. These indicators also further the usefullness of the indicator system for international comparison, esp. for policy goals. The focus is on the role of human capital in the relative competitiveness of national economies. All these indicators are relative, i.e. present a ranking of the participating countries on the dimensions mentioned below.

I.1 relative wage level

a. relative net wages by country;

b. relative net wages by sector per country.

I.2 relative labour productivity

a. relative labour productivity by country;

b. relative labour productivity by sector per country.

I.3 relative level of human capital investment

a. by sector per country the relative share of employment with lower, middle and higher education;

b. by sector per country the relative degree of investment in training.

\section{Structure of employment}

Indicators on the structure of employment offer important background information for interpreting the labourmarket indicators. Also, these indicators might partly be interpreted as 'labour market outcomes' (Rumberger 1994), indicating the succes of the labour market in ensuring employment and of individuals holding specific qualifications in gaining employment. Here especially the participation indexes (II.2) are important. Part of these indicators are parameters in other indicators.

\section{II.1 structure of employment}

a. employment by sector;

b. employment by occupational group;

c. employment by type of education. 


\section{II.2 participation indexes}

Employed, unemployed and inactive persons by type of education as fractions of the 15 - 65 years population.

Breakdowns per gender and age groups.

\section{II.3 gender structure of employment}

a. employed and unemployed persons by gender per sector

b. employed and unemployed persons by gender per occupational group

c. employed and unemployed persons by gender per type of education

II. 4 age structure of employment

a. employment by sector per age group (under 30, $30-49,50$ and over);

b. employment by occupational group per age group (idem);

c. employment by type of education per age group (idem).

\section{II.5 type of employment}

a. employed persons by sector per type of employment (paid employment, self employed, other employment);

b. employed persons by occupational group per type of employment (paid employment, self employed, other employment);

c. employed persons by type of education per type of employment (paid employment, self employed, other employment).

\section{II.6 atypical employment}

II.6.1 part-time work

a. percentage of employed persons working part-time by sector per gender;

b. percentage of employed persons working part-time by occupational group per gender;

c. percentage of employed persons working part-time by type of education per gender.

II.6.2 temporary jobs

a. percentage of employed persons holding temporary jobs by sector per gender;

b. percentage of employed persons holding temporary jobs by occupational group per gender;

c. percentage of employed persons holding temporary jobs by type of education per gender.

II. 7 nationality

a. percentage of other nationalities (from EU - not from EU) per sector;

b percentage of other nationalities (from EU - not from EU) per occupational 
group;

c. percentage of other nationalities (from EU - not from EU) per type of education.

\section{Current labour market balances}

Labour market balances most directly indicate the actual situation of the labour market, in terms of (over)supply or shortages. In interpreting the consequences of labour market (in)balances for specific types of education also a number of risk indicators should be taken into account (see section 3.1). Of these, under- and overeducation are directly related to discrepancies at III; others are shown at IV.

For the supply side, oversupply is directly indicated by unemployment, but for interpretation indicators on cyclical sensitivity (IV.3, indicating if unemployment is cyclical or more structural in nature) and of over-education ( indicating hidden mismatches if people accept jobs at skill levels far under their level of qualification) are also needed.

On the demand side, vacancies directly indicate shortages of supply. It is a weak indicator though, because the registration of vacancies is very partial and the degree of registration differs between countries and between sectors (Muysken 1994). A very low level of unemployment may be interpreted as indicating shortages. Of the risk-indicators, under-education (people aquiring jobs far over their level of qualification) might also indicate shortages. For interpretion shortages, especially the indicators of flexibility (IV.1, IV.2) and cyclical sensitivity (IV.3) are needed. Flexibility indicates if filling of vacancies from a narrow or a more wide range of qualifications might be expected. Cyclical sensitivity indicates a cyclical or more structural nature of shortages. Wages are added as partial indicator of differences in market value. Depending upon the availability and comparability of data, these might be net or gross wages.

These indicators and risk-indicators do not show possible effects of more structural developments, esp. shifts in qualification demand as a consequence of technological and structural changes in employment. Therefore the same indicators are shown for school leavers only (V.2, V.3, V.6). As school leavers are more dependent upon their initial qualification for gaining employment, possibly their position reflects more directly these structural developments.

III.1 Open discrepancies

III.1.1 vacancy rate

a. vacancy rate per sector;

b. vacancy rate per occupational group;

c. vacancy rate per type of education. 
III.1.2 unemployment rate

Unemployment rate by type of education.

III. 2 Hidden discrepancies

III.2.1 rate of overeducation

Percentage of employed persons employed below their level of education by type of education.

III.2.2 rate of undereducation

Percentage of employed persons employed above their level of education by type of education.

III.3 Relationship of open and hidden discrepancies

Per type of education the relation between unemployment and overeducation is graphically indicated in figure 3.1 .

Figure 3.1

The actual labour market situation characterized by means of the rate of unemployment and the rate of overeducation

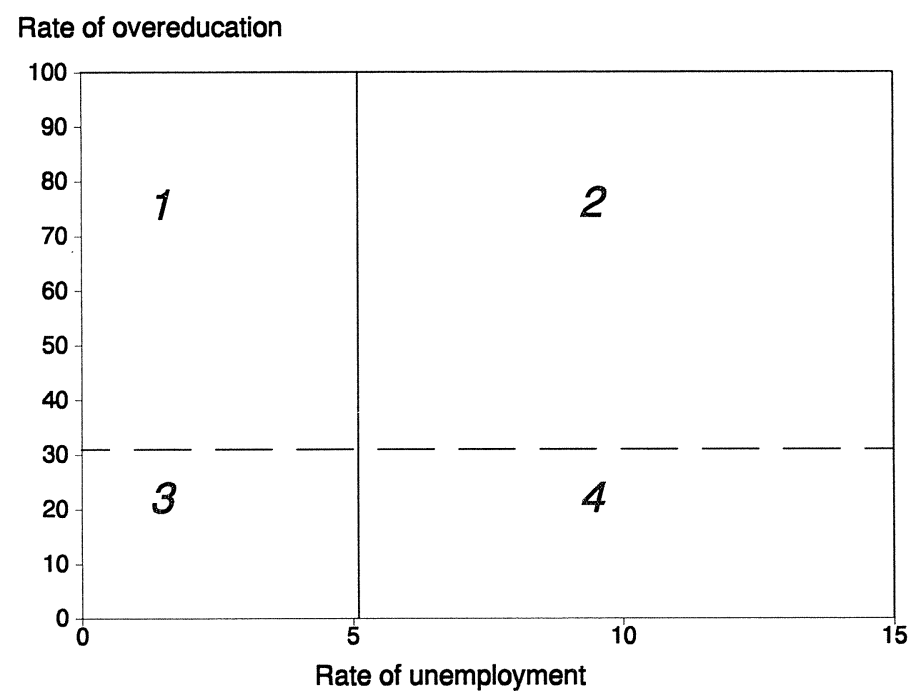

Source: ROA

Figure 3.1 combines the unemployment rates and the rates of overeducation for workers with various educational backgrounds. The combination of these two ratios enables us to give a more general characterization of the current labour market situation of graduates from each type of education. The vertical line gives the 
average national unemployment percentage. The horizontal line gives the average percentage of workers who are over-educated for the position they occupy. The typology shows four typical positions. If both the unemployment rate and the percentage of overeducation is high, workers with that educational background face a poor present labour market situation (2). In that case it will be difficult to find a job and if someone finds work it will often be at too low a level. Conversely, a combination of a low level of unemployment and a low percentage of overeducation can be characterized as a good present labour market situation (3), as in this case the chance of finding a job is high and that job will often be at an adequate level. The labour market situations (1) and (4) fall midway in this typology. In (1), school leavers face no problems in finding a job, but it is often at too low a level compared to their skill level. In (4), school leavers face severe problems in finding a job, although if they obtain a job this is often at an adequate level. The situation in (4) may indicate that there are few opportunities to find work at lower job levels, indicating a direct link between the training of these school leavers and the field of work available to them.

\section{III.4 net wages}

a. average wages by sector;

b. average wages by occupational group;

c. average wages by type of education;

d. average wages by ages group.

\section{Risk indicators}

As stated in section 3.1, the risk indicators have the specific function of adding information for the sake of better interpretation of the indicators directly relating to the labour market. This function has been highlighted in relation to the labour market balance indicators (III). They also have an informative function in relation to the dynamic indicators.

The flexibility of qualified persons indicator indicates the degree to which persons with a particular educational background are dependent upon the employment chances in a particular labour market segment (sector and/or occupational group), or have a wide range of options. The flexibility of recruitment indicator indicates the degree of dependency of a certain educational background in recruiting personel. Cyclical sensitivity has been circumscribed at III.

IV.1 flexibility of qualified persons

IV.1.1 sectoral flexibility by occupational group

Dispersion coefficient over sectors by occupational group. 
IV.1.2 occupational flexibility by type of education

Dispersion coefficient over occupational groups by types of education.

IV.1.3 sectoral flexibility by types of education

Dispersion coefficient over sectors by types of education.

IV.2 flexibility of recruitment

Diversity coefficient over types of education by occupational groups.

IV.3 cyclical sensitivity

a. the fluctuation index of employment by sector;

b. the fluctuation index of employment by occupational group.

\section{Transition from school to work}

For reasons mentioned at III, some indicators on the structure of employment and the labour market balances are repeated here for school leavers only. Added is an indicator of the degree to which school leavers follow additional training, as an index throwing some light upon the degree of preparation of school leavers for their jobs. This indicator is not unidimensional though: following further training might indicate bad preparation, but also (strive for) mobility, changes in job content etc. Thus interpretation is always in combination with other indicators.

V.1 structure of employment of school leavers

a. employment by sector;

b. employment by occupational group;

c. employment by type of education.

Breakdowns per gender and (where data available) per nationality.

V.2 unemployment rate of school leavers

Unemployment rate of schoolleavers by type of education.

\section{V.3 hidden discrepancies}

V.3.1 rate of overeducation of school leavers

Percentage of employed school leavers employed below their level of education by type of education.

V.3.2 rate of undereducation of school leavers Percentage of employed school leavers employed above their level of education by type of education.

V.3.3 relationship of open and hidden discrepancies 
Simular to figure 3.1 per type of education the relation between unemployment and overeducation of school leavers can be graphically indicated in order to give a more general characterization of the current labour market position for the various types of education.

V.4 type of employment of school leavers

Employed schoolleavers by type of education per type of employment (paid employment, self employed, other employment).

\section{V.5 atypical employment}

V.5.1 part-time work

Percentage of employed school leavers working part-time by type of education per gender.

\section{V.5.2 temporary jobs}

Percentage of employed school leavers holding temporary jobs by type of education per gender.

V.6 wages of school leavers

a. mean wages by sector;

b. mean wages by occupational group;

c. mean wages by type of education.

V.7 additional training

a. the fraction of school leavers by sector following further training;

b. the fraction of school leavers by occupational group following further training;

c. the fraction of school leavers by type of education following further training;

d. the fraction of unemployed and of not active school leavers per type of education following further training.

\section{Qualitative developments}

The quantitative information on the labour market, and especially the forecasts of demand (VII.2), reflect qualitative changes only in sofar as there are effects on the job structure. Nevertheless, the changing of job contents is an ongoing proces, due to technological developments, organizational changes and the ongoing pressure on labour productivity. Especially for education and training policy, information on job content change is an essential supplement to the demand forecasts. More generally, information on technological and structural trends are important for policymaking on company-, educational- and political level. These indicators might also contribute to more structured expectations about long term changes in the structure 
of employment.

VI.1 technological and structural trends and expectations

Observations of a qualitative and global nature of technological and structural developments and trends per sector and/or occupational group, and expectations for the near future.

\section{VI.2 degree of job content change}

By occupational group expectations of the degree of job content change over the short term (two years) and medium term (five years).

\section{Future labour market: forecasts and interpretations}

These final indicators reflect the prospects for the near future. Firstly, these prospects are treated quantitatively: the forecasts of supply (labour market inflow) and demand. Secundly, interpretations are formulated qualitatively.

The forecasts of demand are of great importance to labour market and education policies and for educational- and careerchoices. These indexes are complex ones, combining parameters on employment, age structures, labour market participation, types of education and employment forecasts. These parameters are not all shown per se within the indicators. Replacement demand and expansion demand indicate the nature of demand; the expected job openings are the net result, indicating actual demand.

As pointed out at several points above, for drawing conclusions (on the labour market situation and prospects, on chances of individuals etc.) a combination of indicators is wanted. This holds especially for the interpretation of the indicators on labour market balance, related to the risk indicators. Also indicators on qualitative developments might add information to these interpretations.

The potential number of these types of analyses is great; in fact, for any type of monitoring demand or policy request, interpretive analyses have to be made. In this indicator system, two types of analysis are made that are especially relevant to practical and policy goals: on labour market perspectives and on recruitment perspectives.

The labour market perspectives refer to the actual chances on the labour market in the near future (in 2 - 5 years), when those now choosing an option in education will enter the labour market. For this goal, the forecasts of job openings and of the inflow to the labour market are combined; where relevant, expectations on job content change and on technological and structural changes might modify the expected perspectives. The expectations are formulated on the level of the types of 
education, pertaining to chances for occupations in sectors. They are especially relevant for job- and careerchoice guidance and for the policy of schools and 35 guidance agencies.

For the recruitment perspectives, the reverse analysis is made: from occupational groups per sector to types of education. Focus is here the provision in adequately trained personel in the near future (2 - 5 years). This indicator is especially relevant for companies, training agencies and education and labour market policy. Both types of perspectives are formulated qualitatively, in the form of short typologies. For formulating these typologies, a multi-dimensional model will be used in order to make them as 'objective' as possible.

VII.1 inflow of school leavers on the labour market

Inflow of schoolleavers on the labour market by type of education ( 2 - 5 years forecasts).

VII.2 two - five years forecasts of labour demand

a. 2 - 5 years forecasts of expansion demand by sector;

b. 2 - 5 years forecasts of expansion demand by occupational group;

c. 2 - 5 years forecasts of expansion demand by type of education;

d. 2 - 5 years forecasts of replacement demand by sector;

e. 2 - 5 years forecasts of replacement demand by occupational group;

f. 2 - 5 years forecasts of replacement demand by type of education;

g. 2 - 5 years forecasts of job openings by sector;

h. 2 - 5 years forecasts of job openings by occupational group;

i. 2 - 5 years forecasts of job openings by type of education.

\section{VII.3 interpretations}

VII.3.1 labour market perspectives

Typologies by type of education on labour market chances in two and five years on the level of occupational groups per sector.

\section{VII.3.2 recruitment perspectives}

Typologies by occupational groups per sector on chances in two and five years for recruitment of personell trained on the level of relevant types of education. 


\section{Availability of data}

In this chapter the possibilities for generating the various labour market indicators are discussed. This is done in rather general terms. As stated in chapter 1, at this stage it is not yet clear for which institutions in which countries in the EU (or for the EU as a whole) the indicators will be developed. The main goal of the orientation on this point was to give an impression of the feasibility of the indicators for the Member States of the EU. This was done by analysing the type of data sources needed for the respective indicators and by analysing the availability of these data sources in four EU-countries (Belgium, Germany, Great Brittain and The Netherlands).

\subsection{Types of datasources}

Figure 4.1 shows the types of data sources required for the seven categories of indicators.

As the figure shows, four main groups of indicators can be identified.

A first group are the indicators on the comparative position of the national economies, the structure of employment, the current labour market balances, risk indicators and recent trends. These indicators mainly require data from Labour Force Surveys and/or Population Censuses. For indicators on the comparative position of national economies also national account statistics are also required. For indicators on the current labour market (mis)match, administrative or survey data on vacancies and unemployment are also required. For the participation indexes demographic statistics might be needed.

The second group are the indicators on the transition from school to work. If available, surveys on school leavers are the main input. Also longitudinal follow-up studies can be used, provided that a particular point after leaving education can be analyzed transversaly. In some cases and with many limitations, labour force surveys and/or population censuses might also feed these indicators if an adequate number of persons that left school recently can be discriminated within the sample. However, sample sizes of labour force surveys are generally too small to reach the desired level of aggregation for this group, which mean that only very gross figures can be presented.

The third group are indicators on the future labour market, containing short and medium term forecasts. For these indicators, a much more extensive data-input is needed. Firstly, forecasts of major economic developments are required, both on 
macro-economic and at a sectoral level. Typically, these kinds of forecasts are produced by public forecasting or planning agencies, central banks etc. Secondly, starting from the macro-economic- and sector-models, forecasting models with respect to the occupational and educational structure of employment ('expansion demand'), replacement demand and the inflow of newcomers on the labour market are required. Inputs required for these forecasting models are the prementioned national forecasts, labour force surveys and/or population censuses and educational statistics, esp. those on outflow of education and on the destination of pupils and students after certification and outflow.

Figure 4.1

Required data sources for various categories of labour market indicators by economic sector, occupation and educational qualification

Category of indicator Sources

Comparative position of national economies

Structure of employment and recent trends

Current labour market balances

Risk indicators

Transition from school to work

Short and medium term forecasts

Qualitative developments
- National accounts statistics

- Labour Force Survey and/or Population Census

- Demographic statistics

- Registered or survey data on vacancies and unemployment

- Labour force survey and/or school leavers survey

- Labour Force Survey and/or Population Census

School leavers survey and/or Longitudinal follow-up study and/or Labour force survey

- Macro-economic models and sectoral models (various data inputs)

- Occupational models (data input: Labour Force Survey and/or Population Census)

- Educational Qualifications model (data input: Labour Force Survey and/or Population Census)

- Models of labour market inflow of school leavers (data input: educational statistics on outflow and destination)

Expert consultations 
The fourth group are the indicators on qualitative developments. This type of information, on the intended scale and in the form of regularly published indicators, is rather new and experimental. Main source should be some form of structured consultations of 'experts', commenting on quantitative data on relevant trends and developments.

\subsection{Availability of data}

In general, the availability of the datasets is different for the four groups mentioned in section 4.1. As to the first group, all the data sources mentioned are available in some form or another in most or all member states of the European Union. Moreover, most of these data is also available at EUROSTAT, be it often at a rather high level of aggregation. This means that, at least on a high level of aggregation, these indicators can in most cases be produced. However, if more details are wanted, great differences are to be expected per country in reliability and completeness, level of aggregation and classification. The latter in particular holds for the types of education to be distinguished, as the EUROSTAT statistics based on the ISCED-codes only refer to skill levels and a broad distinction between general and vocational education. In some cases, limits to producing parts of the indicators are to be expected.

As to the second group, surveys on school leavers over the whole range of types of education and on a national scale seem to be rather rare. In an inventory in 1993 (ESF-network, 1994), surveys of this nature were found in France, Ireland and The Netherlands. In Italy they expired after 1985. Longitudinal follow-up studies (cohorts) serving comparable functions were found in Spain (only one region), in England and Wales and in Scotland. Incidental or partial studies may occur elsewhere, e.g. Norway - only higher education - and Flanders - only vocational education in one region - (see Denys 1991). In Germany no research of this kind is known. In Flanders some initiative to start a schoolleavers survey is underway. As stated, the indicators of this group might partly be filled from labour force surveys.

As to the third group - short and medium term forecasts - these will also differ from country to country if these indicators can be incorporated. The limiting factor will be the availability of macro-economic forecasts of sufficient detail at a sectoral level and the availability of forecasting models on the occupational and educational structure of employment. Also statistics on educational outflow are not always of sufficient completeness ${ }^{3}$.

3. See section 4.3 for more details on the availability of these indicators in Belgium, Germany, the United Kingdom and the Netherlands. 
The fourth group, already mentioned, is new and experimental in all countries, though much expert signalling does occur for specific branches, regions etc. and on incidental basis. This probably allows for tracing existing expert groups and networks that might form a starting point. Also, systematic analysis of publications in this way might be an alternative way of generating these indicators (see e.g. Borghans et al. 1994).

A general conclusion might be that the proposed set of international indicators contains a 'nuclear group' of status- and current balance indicators, which can be produced in some form in most cases, and a group of indicators that are much more costly to develop for all EU-Member States. It is probably most effective to develop this latter group of indicators gradually, as far as in the various Member States the required datasets develop and quantitative and qualitative forecasting approaches catch on. The complete system of indicators will be an ideal, guiding developments, more than being actually produced in the short term.

\subsection{Analysis for four countries}

The foregoing will be illustrated with some more detailed information on the availability of the required data sources in Belgium, Germany, Great Britain and The Netherlands and from EUROSTAT. Firstly, the main data sources, as mentioned in figure 4.1, will be dealt with, in the following order:

a.1 Labour Force Survey

a.2 Population Censuses

b. 1 statistics on unemployment

b. 2 statistics on vacancies

c. demographic statistics

d.1 school leavers survey

d.2 alternative sources for schoolleavers data

e. national accounts' statistics

f. macro-economic - and sector forecasts

g.1 statistics on student outflow of initial education

g.2 educational statistics on destination of student outflow.

Secondly, if relevant some remarks will be made on specific entities and attributes within these sources.

\section{Belgium}

In Belgium, the institute contacted was the 'Steunpunt Werkgelegenheid, Arbeid en Vorming' WAV, an organisation related to the Higher Institute of Labour HIVA, a research instituted connected with the University of Louvain. Several publications of 
HIVA were studied on the sources and the availability of data (Brusten et al., 1994; Dejonckheere, 1994; Gos et al. 1991). A recent ROA-report on euregional labour market information (Teunis, 1995) also yields information on the availability of data sources in Belgium. Last but not least, the WAV reacted upon specific questions on the availability of data in Belgium.

The general view on the availability of relevant data in Belgium is one of a very rich but also very complicated statistical landscape. In general, the data input needed for the quantitative status and balance indicators and the forecasts is available. This is however not the case for the indicators on schoolleavers.

Apart from the 'standard' datasources, some very extensive administrative datasources are available, especially in the realm of social security agencies. If well adressed, these might yield very detailed data on a wide range of subjects. Problems are the incompatibility of classifications, the delays in the administrative processing of data and the administrative procedures and costs of aquiring data (Dejonckheere, 1994). Nevertheless, these sources might have important additional value, especially in reaching a low level of aggregation.

A complicating factor is the division of the country into three semi-autonomous regions: Flanders, Walloon and Brussels. Part of statistics and administrative data is regional, part (still) national. Sometimes more than one (regional) institute has to be adressed for the same datasource.

As to the main data sources:

a.1 The Labour Force Survey: is available (Steekproefenquête naar de beroepsbevolking SEB; synonym: arbeidskrachtentelling AKT). This survey is done on about 35.000 households. Until now the survey is held on an annual basis, but there are plans for a higher frequency and a greater sample from 1997.

a.2 The Population Census is also available. The last Census refers to 1991. It is a very extensive dataset, but the very slow processing of the data poses a problem for use. The dataset allows for very detailed analyses on a subregional level.

b.1 statistics on unemployment: the administrative data on unemployment, gathered by the Public Employment Services (VDAB for Flanders, FOREM in Walloon, BGDA/ORBEM for Brussels), are relatively complete. The Federal Labour Agency RVA gathers a range of data on (un)employment on national level. Also the Labour Force Survey yields information on unemployment.

b.2 statistics on vacancies: the administrative data on vacancies gathered by the employment services (VDAB, FOREM, BGDA/ORBEM) are not complete, but in 
comparison to other European countries not bad (Brusten et al., 1994). A vacancy survey refering to the entire labour market has been started. Moreover, several regional initiatives have been started in order to signal trends in labour demand at an early stage in a qualitative way (Teunis, 1995).

c. demographic statistics: available.

d.1 School leavers surveys: are not available. VDAB carries out a yearly survey on school leavers in Flanders who are registered as 'unemployed'. Some research on specific types of education and on specific regions is done (Denys, 1991). Plans for a survey on regional scale (Flanders) are underway but retarded.

d.2 alternative sources: the data required may be partly reconstructed from the Labour Force Survey, although only at a high level of aggregation.

e. national accounts' statistics: are published by the National Bank, also on sectoral level. The OECD STAN-database contains figures for the industrial sectors, partly based on estimates (OECD-DSTI, 1994).

f. macro-economic- and sector level forecasts: are published by the Federal Planning Bureau on a regular basis. Twice a year medium-term (5 year) forecasts of employment by economic sector are provided.

g.1 educational statistics on student outflow: numbers of certificated pupils are available. There are no statistics on non certified outflow, but estimates are that $10-15 \%$ of pupils flow out without certification.

g.2 educational statistics on destination: are not available.

As to specific dimensions and attributes: the Labour Force Survey is built up conforming international classifications. Administrative datasources use their own often incompatible classifications.

\section{Germany}

In Germany the Institute for Labour Research (IAB) in Neurenberg has been contacted. The IAB is a research institute of the federal organization of employment services. Several IAB-publications were screened on datasources used (e.g. Bundesanstalt für Arbeit 1993, Franz et al., 1994), as was the statistical yearbook of the Federal Statistics Service (Statistisches Bundesamt 1994). IAB also responded on a written request of ROA for information on availability of information.

The general conclusion on Germany is comparable to that on Belgium. The data needed for the status- and balance indicators are available; forecasts for 
occupational groups are produced by the IAB on a regular basis, so the dynamic indicators can probably be produced, though the precise models for these indicators still have to be produced; data on school leavers are very limited.

There are also vast differences. One pecularity is that all organisations involved have their own institutional structure, also responsible for the statistical information and research in this field. The majority of vocational education, esp. all courses in the apprenticeship system ('Duales System'), belong to this structure and are thus not registered as 'education'. The statistical information on the apprenticeship system is quite extensive and partially compensates for the lack of school leavers surveys.

The unification of 1990 still has its traces in the provision of statistical information. Far from all statistics are yet integrated; in many cases 'federal area East' and 'federal area West' still have to be distinguished. The most important sources of labour market data are integrated since the early 1990s. Longitudinal trends can probably not be figured for 'area East', as the statistics are not consistent with DDRstatistics.

As for the main sources:

a.1 Labour Force Survey: this is the function of the 'Mikrozensus', a $1 \%$ survey of households twice per year. Very detailed information can be derived from the extensive administration on social insurances, the 'Beschäftigungsstatistik', containing data on all employees legally entitled for social insurances. These statistics cover $85 \%$ of the labour force; excluded are only the civil servants and the self employed people. The civil servants are covered by a IAB-survey once every three years; this group appears to be rather stable. On the self employed only the 'Mikrozensus' contains data. Generally the 'Beschäftigungsstatistik" offers more details, containing data on the full range of sector, occupational group, type of education and wages. The 'Beschäftigungsstatistik' is integrated for East and West since 1992, the 'Mikrozensus' since 1991. The gap for the 'area East' is partly filled by a special IAB 'labour market monitor', which will be ended in short term.

a. 2 population census: last census was in 1989. Here the problem again is the slow processing of data. The debate on the necessity of a next census is still going on.

b.1 statistics on unemployment: the Public Employment Services takes care of a rather complete and extensive registration of unemployment, statistically processed by IAB. Additional surveys are done (Strukturerhebung über Arbeitslose). On the 'area East' also data on hidden unemployment are published. However, this data is very controversial. 
b.2 statistics on vacancies: due to a legal duty to register, only recently expired, statistics on vacancies are rather complete compared to other EU-countries. These vacancies are also registered by the Public Employment Services.

c. demographic statistics: available.

d. 1 school leavers survey: is not available.

d.2 alternative sources: In Germany, the Labour Force Survey might also be analysed on data referring to individuals at a certain point after leaving education. Within the 'Beschäftigungsstatistik' a sample is followed longitudinallty, a.o. in order to investigate the labour market effects of the various educational qualifications. Another alternative data source are the statistics on the apprenticeship system. As apprenticeship training always implies a labour contract, these might be interpreted as follow up - data to some extent.

e. macro-economic accounts: is available ('Volkswirtschaftliche Gesamtrechnung').

f. macro-economic and sector level forecasts: available from various sources. IAB produces 10 and 20 years forecasts of labour force, both of the effective and the potential labour force. Experiments have been done with long term forecasts of expansion demand by educational qualification and sectoral developments. $A$ model for medium-term (3-5 years) forecasts is in development. However, this model generates labour market data on a rather high level of aggregation.

g.1 educational statistics on student outflow: statistics on outflow and certification are available for both the schoolbased and the apprenticeship systems. IAB produces a stream model of the educational system, the 'Bildungsgesamtrechnung', showing the yearly in- and outflow of the types of education.

g.2 educational statistics on destination: not available.

As to dimensions and attributes: in all statistical data sources mentioned above national classifications are being used. For the sake of delivering data to EUROSTAT's Labour Force Survey, some work has already been done in translation to the international classifications. The 'Mikrozensus' is almost completely compatible to EUROSTAT.

\section{United Kingdom}

In the United Kingdom, the institute contacted is the Institute for Employment Research (IER), from the University of Warwick. This research institute publishes 
a.o. reviews of the economy and employment, both nationally and regionally. Information was gathered by studying IER publications (e.g. Wilson, Green and Hasluck, 1994; Wilson and Webb, 1995), Moreover IER reacted upon specific questions on the availability of data in the United Kingdom.

Generally, the datasources needed for the quantitative indicators seem to be sufficient, covering most entities and attributes needed.

As to the main sources:

a.1 Labour Force Survey: is available. An important alternative source is the Census of Employment done by the Employment Department every two years (1991 - 1993 - 1995) and the General Household Survey. The Census of Employment is addressed to establishments and companies. This census has been replaced by a yearly sample survey from 1995 onwards.

a.2 Population Censuses are held every 10 years, the last one was done in 1991.

b.1 Statistics on unemployment: are available from two sources: the Labour Force Survey and the administration of registered unemployment. The latter is not very workable for research purposes, due to o.a. changes in definition.

b.2 Statistics on vacancies: are available from the registration of vacancies by the Employment Department. This source is very incomplete and biased, and does not offer data on vacancies per type of education. There are incidental surveys on vacancies.

c. demographic statistics: available

d.1 school leavers survey: not available on secundary education level. Some incidental surveys are available. University graduates take part in the 'first destinations survey', carried out on a regular basis by the universities (Van Dam e.a, 1989).

d.2 altemative sources: the extensive Youth Cohort Study on England and Wales, and the comparable Scottish Young People's Survey, done every two years, may yield comparable data. The Labour Force Survey is probably not needed for this.

e. national accounts statistics are available. The Central Statistical Office (CSO) publishes several trend studies, including productivity figures per sector.

f. macro-economic- and sectoral forecasting models: the Treasury publishes macro-economic forecasts. About six other institutes regularly publish several types of forecasts, including some sectoral detail, but these are generally very aggregate. IER uses a macroeconomic and employment scenario corresponding 
to that published by Cambridge Econometrics (Wilson and Webb, 1995).

g.1 educational statistics on outflow: a registration of aquired qualifications is present. This is not complete though, due to changes in educational system and because part of vocational training is or was not registered as 'education'. An alternative source on vocational qualifications is the Labour Force Survey. Scotland has a different educational system from England and Wales, so probably a distinction is needed within these indicators.

g.2 educational statistics on destination: some surveys on destination of specific outflows are carried out.

As to some specific dimensions and attributes: for sectors and occupations national classifications are used. These are close to, but not completely identical to, NACE resp. ISCO. With some assumptions, translation to NACE and ISCO is possible. As to 'type of education': the available data seem mainly to bear upon qualifications. As a consequence of the peculiar English educational system, in which part of vocational education takes place outside the schoolsystem, translation to the intended 'types of education' might pose some problems. Moreover, as Northern Ireland is not included in some of the data sources mentioned, part of the available data do not refer to the United Kingdom but Great Britain.

\section{The Netherlands}

As the proposed system of International Labour Market Indicators is developed to the model of the ROA information system on education and the labour market, data are available on the Netherlands for all quantitative indicators. For low levels of aggregation, regulations on the protection of privacy may pose limitations to the publication of data. ROA itself generates part of these data, especially the school leavers surveys. More important, ROA combines own data and data from other institutes, especially Statistics Netherlands, into the information system prementioned.

As to the main sources:

a.1 Labour Force Survey: is available, on a continuing basis (Enquête Beroepsbevolking). Annually $1.1 \%$ of the households are surveyed.

a.2 population censuses: are no longer available. This type of data is sufficiently generated by other surveys and statistics.

b. 1 statistics on unemployment: fairly complete data are available, based upon the administration of the social security system, but data on educational background in particular are insufficient.

b.2 statistics on vacancies: are available, but registered data are of limited value 
due to the limited public registration of vacancies. Survey data from Statistics Netherlands is on a high level of aggregation. ROA therefore uses very low unemployment rates (i.e. below frictional unemployment) as an alternative indicator of supply shortages.

c. demographic statistics: available.

d.1 school leavers survey: on secondary and higher professional education ROA carries out extensive surveys (RUBS and HBO-Monitor) yielding fairly complete data at a low level of aggregation. As to university education, surveys are done by and for part of the universities. Plans are underway for a survey on the whole university system.

d.2 alternative sourves: also here the Labour Force Survey EBB might yield some data on the position of schoolleavers at a higher level of aggregation, but these seem not to be needed for the indicators.

e. national account statistics: available.

f. macro-economic- and sector forecast models: are available from the National Planning Agency (Centraal Planbureau).

g.1 statistics on student outflow: are available for all types of education, distinguishing diplomated and non-diplomated outflow.

g.2 educational statistics on destination of outflow: the so-called matrix statistics on education yield $100 \%$ data on destination within the educational system or outflow out of education. Destination outside education is surveyed in the RUBS and HBO-Monitor surveys (see at d.1).

\section{EUROSTAT}

Luxembourg is the base of the European Union's Statistical Office Eurostat. This institution has large data sets available on a wide variety of subjects mainly regarding the Member States of the European Union. Eurostat's main themes in statistics are:

1. General Statistics;

2. Economy and Finance;

3. Population and Social Conditions;

4. Energy and Industry;

5. Agriculture, Forestry and Fishing;

6. Foreign Trade;

7. Services and Transport;

8. Miscellaneous. 
The data available make it possible to compare countries within a large range of subjects. The general conclusion is that it is possible to produce most of the structural indicators and the 'risk indicators' for all EU-countries, but not the balance- and dynamic indicators. Moreover, the indicators that can be produced are on high level of aggregation: 1 digit.

As to the datasources analysed in this section:

a.1 The Labour Force Survey: The most important source of information within EUROSTAT is the Labour Force Survey. The Labour Force Survey is based on the Labour Force Surveys of the Member States of the European Union and offers a broad variety of indicators regarding the Labour Force. Since 199160 economic sectors (Nace Rev. 1), 111 occupations (ISCO-88) and 244 regions within the 12 Member States are distinguished. The data refer to demographic background, Work status, Employment characteristics of the job (economic sector, occupation, company size, part-time work, temporary contracts, looking for another job, etc.), previous work experience of person not in employment, search for employment, situation of inactive persons, education and training, and situation one year before the survey.

a.2 The population censuses: is not present on EU-level.

b.1 statistics on unemployment: The Labour Force Survey also contains data with regard to unemployment. From 1992 onwards it is even possible to find the reason for becoming unemployed and to distinguish between unemployed and inactive persons.

b.2 statistics on vacancies: Data with regard to vacancies are not available at EUROSTAT.

c. demographic statistics: EUROSTAT has demographic statistics available for the whole population of the Member States of the European Union. EUROSTAT is also responsible for long-term demographic forecasts.

d.1 School leaver surveys: At EUROSTAT there are no school leaver surveys available.

d.2 altemative sources: as was proposed for the single countries, the Labour Force Survey data might be analysed to find data on people who recently left education.

e. macro-economic accounts: Within EUROSTAT the National Accounts of all Member States are available (including value added, earnings of employees, gross fixed capital formation, final consumption of households, financial transactions, etc). Also balance of payment statistics are available and detailed 
studies of various sectors of industry, agriculture, forestry and fishing, and services and transport.

f. macro-economic and sectoral level forecasts: There are no macro-economic and sectoral level forecasts available at EUROSTAT.

g.1 educational statistics on student outflow: Recently EUROSTAT has published, in co-operation with the OECD, a report regarding the outflow of students. In general only the level of education is available according to the ISCED-codes. However, for university students also the various types of education are available.

g.2 educational statistics on student outflow to destination: In principle there are no data available on this subject. However, with help of the retrospective questions it is possible to find the school leavers who have entered the labour market within the Labour Force Survey. From these results an estimation of the first destination of school leavers can be made. 



\section{Concluding remarks}

In the preceding chapters, it is indicated that it is possible both to sketch a system of indicators with a sound theoretical foundation and a clear view on practical use and to give an impression of the feasibility of the system as far as the availability of data is concerned. The general conclusion is that part of the quantitative indicators, especially the structure- and balance indicators, can readily be developed for almost all EU countries. For the dynamic indicators the situation is more diverse. The development of forecasting activities for both occupational categories and types of education in the various Member States will be necessary for generating the indicators on the future labour market. Also the indicators on school leavers will yield a diverse outcome, ranging from complete coverage to no survey activity at all. On the point of the qualitative indicators it is to be expected that the availability of signaling practices to begin with will show a large diversity in the various EU Member States.

What does this mean for the actual development a system of international labour market indicators? It is clear that a simple proposal to develop the system for all EU-countries would make no sense. The costs and the lack of perspective on a complete set of indicators for each country within the foreseeable future would make this road impassable. Also a development strategy set out from a central initiative would run the risk of not reaching what the system of indicators proposed is meant to be: supportive to the activities of all kinds of institutions and persons in the realms of the labour market, education and (national) economic policy making.

What would then be the advice on developing this system? Generally, a very pragmatic strategy is recommended, giving way to partial development of some of the indicators (leaving others for later development) and to developments joining up with other initiatives and with the work of a diversity of institutes active in this field. However, by maintaining some sort of coordinating point and/or central initiative, the final perspective of a comprehensive system will not get lost.

There is more than one way to realize this pragmatic strategy. However, these various ways are not mutually exclusive. Several parallel development paths might be taken, leading the various parts of the proposed system to the final goal. Four main ways seem to be feasible:

1. development for single countries. In this strategy, national institutions with a strong position in the field of labour market research take coordinated but independant initiatives. They take care of developing the national contribution to the system, based on nationally available datasets, with the aid of national funds (with or without support from EU-funds). They also maintain a 
coordinating network structure with a view to developing a comprehensive system and later expansion to other countries.

2. joining other initiatives. In this strategy, existing and coming initiatives on EU scale are joined in order to develop part of the set of indicators relevant to this initiative. An example might be the CIRETOQ - initiative of CEDEFOP. By combining initiatives and maintaining some form of coordinating point, a more or less comprehensive system might be reached in course of time.

3. joining EU monitoring initiatives. Of course it must not be excluded that direct EU-support for developing (parts of) the system might be aquired, especially joining up with the development of monitoring systems on the integration of the labour markets and on specific EU-initiatives. Also the EURES-network might be a starting point. This strategy has advantages, as long as the main goal of the project, i.e. supporting the work of the various institutions in the relevant fields, will not be overlooked. Central points here are a low level of aggregation and priority of completeness with regard to all relevant economic sectors, occupations and educational qualifications over international comparability.

4. development for single institutions. Last but not least, institutions in the intended fields of action might take the initiative and financially support developing (parts of) the system. Examples might be the Public Employment Services, career guidance institutes, Ministries of education, labour and economic affairs and/or international organizations of these types of institutions. Also here, maintaining some form of central coordination might help these initiatives contribute towards the development of a comprehensive system. 


\section{Literature}

Arents, A., H. Heijke, M. Koeslag, A Comparison of the Labour Market Position of University Education and Higher Vocational Education in Economics and Business Administration, ROA-RM-1996/1E, Maastricht, 1996.

Bastelaer, A. van, J. Laan, The Job Vacancy Survey in the Netherlands, in: J. Muysken (ed.), Measurement and Analysis of Job Vacancies, an International Comparison; Avebury, 1994.

Beruf aktuell, Überreicht von der Berufsberatung des Arbeitsamtes, Ausgabe 1994/95.

Borghans, L., Educational Choice and Labour Market Information, ROA, Maastricht, 1993.

Borghans, L., A. de Grip, J. Hoevenberg, De bruikbaarheid van deelmarktinformatie voor het informatiesysteem onderwijs-arbeidsmarkt, ROA-R-1994/13, Maastricht, 1994.

Bottani, N., A. Tuijnman, International Education Indicators, Framework, Development and Interpretation, in: OECD, Making Education Count, Developing and Using International indicators, OECD, Paris, 1994.

Bundesanstalt für Arbeit, Ausbildung - Beschäftigung - Zukunftaspekte; anerkannte Ausbildungsberufe in regionaler Gliederung, Ausgabe 1993.

Bundesanstalt für Arbeit, Bildung und Beruf regional, Bildungsraum Aachen/Düren; berufliche grundbildung, Ausbildung und Umschulung, Studiengänge an Hochschulen, berufliche Weiterbildung, BW Bildung und Wissen Verlag, Nürnberg, 1993.

Brusten, G, P. de Coninck, B. van Schel, Measurement and Analysis of Vacancies in Flanders, in: Muysken, J. (ed.), Measurement and Analysis of Job Vacancies, an International Comparison, Avebury, 1994.

CBS, Standaardberoepenclassificatie 1992, CBS/SDU, 's Gravenhage, 1993.

CEDEFOP, Proposals of CEDEFOP Concerning Topics to be Pursued in the Framework of CIRETOQ in 1995, Berlin, 1995.

Commission of the European Communities, Employment Observatory, Trends, Changes in Employment, Analyses, Evaluations; Series produced from the SYSDEM-Network, Brussels, 1994.

Commissie van de Europese gemeenschappen, EURES, het nieuwe netwerk van informatie over de werkgelegenheid, Brussel, 1992.

Cörvers, F., The Impact of Human Capital on Labour Productivity in Manufacturing Sectors of the European Union; contribution to the Seventh Annual Conference of the European Association of Labour Economists (EALE), Lyon, 7 - 10 September 1995.

Cörvers, F., A. de Grip, Explaining Trade in Industrialized Countries by Country-Specific human Capital Factor Endowments, ROA-RM-1995/3E, Maastricht, 1995.

Cörvers, F., A. de Grip, J.-P. Orbon, Concurrentiekracht, productiviteit en human capital: een vergelijking tussen Nederland en Duitsland, Maandschrift Economie, 59(1995) pp. 221-241.

Dam, J.W. van, J.A.M. Heijke, G.W.M. Ramaekers, Ontwerp van een arbeidsmarktscanner voor academici, ROA-R-1989/3, Maastricht, 1989.

Dejonckheere, $\mathrm{H}$, Regionale arbeidsmarktinformatie in Vlaanderen, Tijdschrift voor arbeidsvraagstukken 10(1994)1.

Dekker, R., De relatie tussen scholing en loopbaan vanuit een arbeidsmarkttheoretische invalshoek, ROA-W-1994/6, Maastricht, 1994.

Dekker, R.J.P., A. de Grip, L. Borghans, A.G.W. Matheeuwsen, M.H. Wieling, E.J.T.A. Willems, Methodiek van het informatiesysteem onderwijs - arbeidsmarkt 1993, ROA-W1993/3, Maastricht, 1993.

Denys, J., Winnaars en verliezers op de arbeidsmarkt, Hoger Instituut voor de Arbeid HIVA KU Leuven, 1991. 
ESF - network on transitions in youth, Newsletter, 1(1994)1.

EUROSTAT, Labour Force Survey, Methods and Definitions, 1992 series, Luxembourg, 1992.

Europese Commissie, Directoraat-Generaal V, Waarnemingspost voor werkgelegenheid, 2/1994.

Eijs, P. van, H. Heijke, The relation between the quality of the match between occupations and types of education, wages and job-related training, ROA, Maastricht, 1996 (forthcoming).

Franz, W., W. Smolny, The Measurement and Interpretation of Vacancy Data and the Dynamics of the Beveridge Curve, the German Case, in: Muysken, J. (ed.), Measurement and Analysis of Job Vacancies, an International Comparison, Avebury, GB, 1994.

Frederix, L.L.M., Th. Mensen, Klantgerichte informatie over onderwijs en arbeidsmarkt in de Euregio; Beroepsopleiding (CEDEFOP), 1993 nr. 1.

Gos, E, J. Pacolet, Plus est en vous; kwalificatieverschuivingen en toekomstperspectieven op de Belgische arbeidsmarkt, Hoger Instituut voor de Arbeid HIVA, Leuven 1991.

Grip, A. de, Meer licht op de regionale arbeidsmarkt, ROA-R-1991/4, Maastricht, 1991.

Grip, A. de, H. Heijke, Manpower Planning and Labour Market Indicators, (unpublished draft).

Grip, A. de, P. Meijboom, E. Willems, Vacatures, werkgelegenheidsontwikkeling en de vraag naar nieuwkomers op de arbeidsmarkt, tijdschrift voor politieke economie, 18(1995)1.

Hoevenberg, J., A. de Grip, Indicators of Occupational Employment in the European Union, ROA-R-1994/3E, Maastricht, 1994.

Hoevenberg, J., P.J.E. van de Loo, R.K.W. van der Velden, Instruments for Analysing Skills Shortages; ROA-W-1994/5E, Maastricht, 1994.

Heijke, prof. dr. J.A.M., Achtergronden en opzet van het informatiesysteem onderwijs-arbeids markt van het ROA, in: Spijkerman, R.M.H., A.J.R. Vincken, M.J.M. Weekenborg (red.), Handboek studie- en beroepskeuzevoorlichting, Samson H.D. Tjeenk Willink, Alphen aan den Rijn, 1993.

Heijke, H., A. de Grip, Mismatches Between Education and the Labour Market, in: Jaspers, T., J. Schippers, J. Siegers, I. Van Berkel (eds.), Working Policies ? Facts, Aanalyses and Policies Concerning Employment and Non-participation in The Netherlands, WoltersNoordhoff, Groningen, 1995.

Jos, O., Indicators of Network B, a Collection of Descriptions of the Network B Indicators in Terms of Definitions, Basic Data, Breakdowns and Calculation Formulas, draft document, OECD, Paris, 1995.

Laan, L. van der, Regionale arbeidsmarktinformatie, EGI, Rotterdam, 1992.

LDC, Kansen op werk 2000; arbeidsmarktperspectieven van opleidingen en beroepen, LDC, Leeuwarden, 1993.

Muysken, J. (ed.), Measurement and Analysis of Job Vacancies, an International Comparison, Avebury, 1994.

Nuttall, D., Choosing Indicators, in: OECD, Making Education Count, Developing and Using International indicators, OECD, Paris 1994.

OECD, Making Education Count, Developing and Using International indicators, OECD, Paris, 1994.

OECD-DSTI, The OECD STAN Database for Industrial Analyses 1972-1991, OECD, Paris, 1994.

OECD, Employment Outlook, Paris, 1995.

Pacolet, J., C. van der Voorde, Toekomstperspectieven op de Belgische arbeidsmarkt, Werkgelegenheid, Arbeid, Vorming, nieuwsbrief van het steunpunt WAV, 4(1994)1. 
PETRA national centre in the Netherlands/LDC, Labour Market Information in Guidance; Report of an Expert Meeting 24 - 25 February 1994, Leeuwarden, 1994.

ROA, The Labour Market by Education and Occupation to 1998, ROA-R-1993/10E, Maastricht, 1993.

ROA, The Labour Market by Education and Occupation to 2000, ROA-R-1995/3E, Maastricht, 1995.

Rumberger, R.W., Labour Market Outcomes as Indicators of Educational Performance, in: OECD, Making Education Count, Developing and Using International Indicators, OECD, Paris, 1994.

Sellin, B, The Need for Effective Information Systems for Education and Training Policies for Europe, CEDEFOP, Berlin, 1991.

Sheldon, G., Die berufliche und geographische Flexibilität, Institut für Arbeitsmarkt und Berufsforschung der Bundesanstalt für Arbeit, Beitrage AB92, Nürnberg, 1985.

Statistisches Bundesamt, Statistisches Jahrbuch 1994 für die Bundesrepublik Deutschland, Wiesbaden, 1994.

Teunis, U., Informatiesysteem onderwijs-arbeidsmarkt voor de Euregio Maas-Rijn, ROA-R1995/2, Maastricht, 1995.

Thomas, G., Future Developments of the Community Labour Force Survey, ECE/EUROSTAT Joint work session on demographic projections, working paper no. 52 , Luxembourg, 1994.

Warnken, J., Zur Entwicklung der 'internen' Anpassungsfähigkeit der Berufe bis zum Jahre 2000. Projektionen unter den Annahmen der Wachstumsszenarien der Prognos-Studie, Mitteilungen aus der Arbeitsmarkt und Berufsforschung, 1 (1986), pp. 119-133.

Wegerif, M., The Use of Vacancy Data by the Dutch Employment Service, in: Muysken, J. (ed.), Measurement and Analysis of Job Vacancies, an International Comparison, Avebury, 1994

Wilson, R.A., A.E. Green, C. Hasluck, Review of the Economy and Employment 1994, Regional Assessment, Institute of Employment Research, University of Warwick, 1994.

Wilson, R.A., T.J. Webb, Review of the Economy and Employment 1995, Occupational assessment, Institute of Employment Research, University of Warwick, 1995.

Windham, D.M., Effectiveness Indicators in the Economic Analysis of Educational Activities, in International Journal of Educational Research, 12(1988), pp. 575 - 666.

Zandvliet, C. Th., A.C.H. Hammink, H.W. Knol, S. Romkema, Internationale arbeidsbemiddeling, OAV-rapport 91-10, Arbeidsvoorziening, Rijswijk, 1991. 